\title{
TINGKAT PENGETAHUAN KELUARGA TENTANG CARA PERAWATAN PASIEN FRAKTUR DI RSUD ARIFIN ACHMAD
}

\author{
Ade Yelda Hastriati \\ Fakultas Kedokteran dan Ilmu Kedokteran, universitas Abdurrab \\ Email:adeyelda@gmail.com
}

\begin{abstract}
Fracture is breaking of bone kontinitas which because of physical energy or trauma resulting venous damage and oedema. Knowledge Family very having an effect on and play important role in course of healing fraktur patient. Target of this research to know how picture mount knowledge of family about way of treatment of patient Fraktur patient at home in RSUD Arifin Achmad Pekanbaru. Research type is is quantitative, with descriptive. Population in this research is all natural patient family of taken care of by Fracture in Room Dahlia RSUD Arifin Achmad. intake of Sample in this research use total technique of sampling with amount of sample in this research 36 people. Research appliance that is using and quistioner management of data use editing, coding, tabulating, cleaning, and data entry. Research done on 15 April until 20 April 2013. From result of analysis got by majority responder have age to 20-29 year counted 14 people (38,8\%), majority knowledge of responder about congeniality of Fracture enough counted 17 people (42,2\%), majority knowledge of responder about way of good Fracture patient immobilizes that is counted 14 people (38,9\%), majority knowledge of responder about requirement of nutrition at Fracture patient less that is counted 22 people (61,1\%), majority knowledge of responder about prevention of infection enough that is counted 21 people $(58,3 \%)$. From result of overall of majority knowledge of responder about picture mount knowledge of family about fracture patient cures at home that is enough counted 17 people (36,1\%). And expect to health energy earning more is giving education health specially fraktur patient family to home can take care of fraktur patient at home.
\end{abstract}

Keyword : Family, Fractur, caring

ABSTRAK

Fraktur adalah terputusnya kontinitas tulang yang disebabkan oleh trauma atau tenaga fisik yang mengakibatkan oedema dan kerusakan pembuluh darah. Pengetahuan keluarga sangat berpengaruh dan berperan penting dalam proses penyembuhan pasien fraktur. Tujuan penelitian ini untuk mengetahui bagaimana gambaran tingkat pengetahuan keluarga tentang cara perawatan pasien Fraktur di rumah di RSUD Arifin Achmad Pekanbaru. Jenis penelitian adalah kuantitatif, dengan desain deskritif. Populasi dalam penelitian ini adalah seluruh keluarga pasien yang mengalami Fraktur yang dirawat di Ruang Dahlia RSUD Arifin Achmad. Pengambilan sampel dalam penelitian ini menggunakan teknik total sampling dengan jumlah sampel dalam penelitian ini 36 orang. Dari hasil analisa didapatkan responden mayoritas berusia 20-29 tahun sebanyak 14 orang (38,8\%), mayoritas pengetahuan responden tentang pengertian Fraktur cukup sebanyak 17 orang (42,2\%), mayoritas pengetahuan responden tentang cara imobilisasi pasien Fraktur baik yaitu sebanyak 14 orang $(38,9 \%)$, mayoritas pengetahuan responden tentang asupan gizi pada pasien Fraktur kurang yaitu sebanyak 22 orang (61,1\%), mayoritas pengetahuan responden tentang pencegahan infeksi cukup yaitu sebanyak 21 orang (58,3\%). Dari hasil keseluruhan mayoritas pengetahuan responden tentang gambaran tingkat pengetahuan keluarga tentang cara perawatan pasien fraktur di rumah yaitu cukup sebanyak 17 orang (36,1\%). Dan harapkan kepada tenaga kesehatan agar dapat lebih memberikan pendidikan kesehatan khususnya keluarga pasien fraktur yang akan pulang agar dapat merawat pasien fraktur di rumah.

Kata Kunci : Keluarga, Fraktur, cara perawatan, 


\section{PENDAHULUAN}

Fraktur atau patah tulang adalah terputusnya kontinuitas tulang dan tulang rawan yang disebabkan oleh trauma atau tenaga fisik (Silvia, 2001). Fraktur terjadi jika tulang dikenai stress yang lebih besar dari yang dapat diabsorbsinya, yang disebabkan oleh pukulan langsung, gaya meremuk, gerakan mendadak dan kontaksir. otot ekstern. Meskipun patah tulang, jaringan sekitarnya juga akan terpengaruh, mengakibatkan edema jaringan lunak dan kerusakan pembuluh darah. Organ tubuh dapat mengalami cedera akibat gaya yang disebabkan oleh fraktur atau fragmen tulang (Brunner \& Suddarth, 2002).

Gejala fraktur yang paling umum di antaranya adalah adanya rasa sakit atau nyeri yang akan bertambah berat dengan gerakan dan penekanan atau fraktur dan mungkin juga terkait dengan hilang fungsinya (Reeves, 2001)

Berdasarkan data yang diperoleh dari rekam medik Rumah Sakit Umum Daerah Arifin Achmad tahun 2017 (periode Januari sampai dengan Desember), penderita fraktur berjumlah 51 orang. Dan untuk tahun 2018 (periode Januari sampai dengan Desember), penderita fraktur berjumlah 96 orang.

Tujuan Penelitian, untuk mengetahui tingkat pengetahuan keluarga tentang pengertian fraktur, mengetahui tingkat pengetahuan keluarga tentang cara imobilisasi pada pasien fraktur, dan untuk mengetahui tingkat pengetahuan tentang cara meningkatkan gizi pada pasien fraktur

Pengetahuan adalah hasil dari tahu dan terjadi setelah orang melakukan penginderaan terhadap suatu objek tertentu. Penginderaan terjadi melalui panca indera manusia, yakni indera penglihatan, pendengaran, penciuman, rasa dan raba. Sebagian besar pengetahuan manusia diperoleh melalui mata dan telinga (Notoatmodjo, 2010). Pengetahuan atau kognitif merupakan domain yang sangat penting untuk terbentuknya tindakan seseorang (over behavior) (Notoatmodjo, 2003).

\section{Tingkat Pengetahuan}

1. Tahu (Know), tahu diartikan sebagai mengingat suatu materi yang telah dipelajari sebelumnya. Termasuk ke dalam pengetahuan tingkat ini adalah mengingat kembali (recall) terhadap suatu yang spesifik dari seluruh bahan yang dipelajari atau rangsangan yang telah diterima. Oleh sebab itu, "Tahu" ini adalah merupakan tingkat pengetahuan yang paling rendah. Kata kerja untuk mengukur bahwa orang tahu tentang apa yang dipelajari antara lain: menyebutkan, menguraikan, mendefinisikan, menyatakan dan sebagainya.

b. Memahami (Comprehension)

Memahami diartikan sebagai suatu kemampuan menjelaskan secara benar tentang objek yang diketahui dan dapat menginterpretasikan materi tersebut secara benar.

c. Aplikasi (Application)

Aplikasi diartikan sebagai kemampuan untuk menggunakan materi yang telah dipelajari pada situasi atau kondisi riil (sebenarnya). Aplikasi disini dapat diartikan aplikasi atau penggunaan hukum-hukum, rumus-rumus, metode, prinsip dan sebagainya dalam konteks atau situasi yang lain.

\section{d. Analisis (Analysis)}

Analisis adalah suatu kemampuan untuk menjabarkan materi atau suatu objek ke dalam komponen-komponen, tetapi masih di dalam suatu struktur organisasi tersebut, dan masih ada kaitannya satu sama lain. Kemampuan analisis ini dapat dilihat dari penggunaan kata-kata kerja seperti, dapat menggambarkan, 
membedakan, memisahkan, mengelompokkan dan sebagainya.

e. Sintesis (Syntesis)

Sintesis menunjuk kepada suatu kemampuan untuk meletakkan atau menghubungkan bagian-bagian di dalam suatu bentuk kesuluruhan yang baru

f. Evaluasi (Evaluation)

Evaluasi ini berkaitan dengan kemampuan untuk melakukan justifikasi atau penilaian terhadap suatu materi atau objek.

\section{Definisi Fraktur}

Fraktur adalah patah tulang yang biasanya disebabkan oleh trauma atau tenaga listrik (Michael, 1999) Fraktur atau patah tulang adalah terputusnya kontinuitas jaringan tulang dan/atau tulang rawan yang umumnya disebabkan oleh rudapaksa (Gustillo, 2000).

Fraktur adalah terputusnya kontinuitas tulang dan atau rawan (Junaidi, 2002).

Berdasarkan pengertian di atas, maka dapat disimpulkan bahwa fraktur adalah terputusnya kontinuitas tulang dan atau tulang rawan yang biasanya disebabkan oleh trauma atau tenaga fisik dan biasanya disertai cedera jaringan disekitarnya yaitu ligamen, otot, tendon, pembuluh darah dan persyarafan.

Menurut Jenis Fraktur, dapat dibagi menjadi

a. Fraktur tertutup (Closed), bila tidak terdapat hubungan antara fragmen tulang dengan dunia luar.

b. Fraktur terbuka (Open/Compound), bila terdapat hubungan antara fragmen tulang dengan dunia luar karena adanya perlukan di kulit, fraktur terbuka terbagi atas tiga derajat (Gustillo , 2000) yaitu :

1) Derajat I
a) Luka $<1 \mathrm{~cm}$
b) Kerusakan jaringan lunak sedikit, tak ada tanda luka remuk
c) Fraktur sederhana, transversal, oblik atau kominutif ringan
d) Kontaminasi minimal

2) Derajat II a) Laserasi $>1 \mathrm{~cm}$

b) Kerusakan jaringan lunak, tidak luas, flup/avulse

c) Kontaminasi sedang

3) Derajat III

Terjadi kerusakan jaringan lunak yang luas, meliputi struktur kulit, otot, dan neurovaskuler serta Kontaminasi derajat tinggi.

\section{Klasifikasi Fraktur}

a. Menurut bentuk patah tulang

1) Fraktur komplit, apabila seluruh tulang patah dan tulang menjadi dua pigemn

2) Fraktur inkomplit, patah tulang sebagian tanpa terjadi pemisahan tulang.

3) Fraktur tertutup , dimana kulit tidak ditembus oleh tulang.

4) Fraktur terbuka, tulang yang patah menembus kulit sehingga tulang kelihatan

5) Fraktur tanpa perubahan posisi , tulang mengalami patah sedangkan posisinya pada tempatnya.

6) Fraktur dengan perubahan posisi , tulang yang patah berjauhan dari tempat patah

7) Comminuted fraktur, serpihanserpihan atau terputusnya keutuhan jaringan terdapat lebih dari dua fragmen.

8) Impacted fraktur, salah satu ujung tulang yang patah menancap pada yang lain.

Menurut garis patah tulang

1) Fraktur Greenstica, yaitu salah satu dari sisi tulang patah, biasanya terjadi pada anak-anak yang tulang masih lunak.

2) Fraktur transverse, fraktur yang garis patahnya tegak lurus terhadap tulang.

3) Fraktur obligue, fraktur yang garis patahnya membentuk sudut tulang.

4) Fraktur spiral, fraktur yang timbul akibat kursi pada ekstremitas dan dapat cepat sembuh dengan imobilisasi eksternal (Noer, at all, 1999). 


\section{Penyebab}

Trauma pada tulang :

a. Langsung, akibat proses patologik (Fraktur tejadi atau trauma akibat kecelakaan bermotor

Benturan dan cedera, seperti jatuh atau trauma akibat kecelakaan bermotor.

b. Tidak langsung

1. Fraktur patologi dapat disebabkan karena kelemahan tulang akibat penyakit kanker

2. Fraktur karena letih atau karena otot tidak dapat mengabsorbsi energi seperti karena berjalan kaki terlalu jauh.

3. Penyakit-penyakit lain seperti astreumelitis.

\section{Manifestasi Klinis}

Perubahan posisi dan bengkak (deformitas) dapat terjadi berisi cairan serous pada sisi sekitar fraktur serta jaringan berdekatan (Echimosi) perdarahan berasal dari jaringan subkutan (Spasme otot) kontraksi invulunter dari otot yang berdekatan dengan fraktur (bagian yang lunak "Dengan Palpasi") pada sekitar sisi fraktur (nyeri) tiba-tiba nyeri hebat setelah injuri, nyeri akibat spasme otot, nyeri kerusakan jaringan (gangguan sensori) dapat terjadi karena kerusakan syaraf (gangguan fungsi normal) disebabkan karena tidak stabilnya tulang yang patah, nyeri, spasme otot, parayse akibat hilangnya/rusaknya fungsi syaraf (gangguan mobilisasi) (adanya krepitasi), (shock) adanya kehilangan darah, fraktur lain nyeri hebat/ kerusakan jaringan (kelainan X-Ray).

\section{Penatalaksanaan}

Fraktur biasanya menyertai trauma, untuk itu sangat penting untuk melakukan pemeriksaan terhadap jalan nafas (Air Way). Proses pernafasan (breathing), dan sirkulasi (circulation) apakah terjadi syok atau tidak. Bila sudah dinyatakan tidak ada masalah lagi, baru lakukan anamnesa dan pemeriksaan fisik secara terperinci. Waktu terjadinya kecelakaan penting ditanyakan untuk mengetahui berapa lama sampai di Rumah Sakit. Bila lebih dari 6 jam, komplikasi infeksi bisa terjadi, lakukan anamnesis dan pemeriksaan fisik secara tepat, singkat dan lengkap. Kemudian, lakukan foto radiologis, pemasangan kayu penyangga dan dilakukan untuk mengurangi rasa sakit dan mencegah terjadinya kerusakan yang lebih berat pada jaringan lunak selain memudahkan proses pembuatan foto. Pengobatan fraktur tertutup biasanya konservatif atau operatif

\begin{tabular}{|c|c|c|c|c|}
\hline alam & No & Kategori & $\begin{array}{l}\text { Frekuensi } \\
\text { (f) }\end{array}$ & $\begin{array}{l}\text { Persentase } \\
(\%)\end{array}$ \\
\hline pene & 1 & Baik & 10 & 27,8 \\
\hline tian & 2 & Cukup & 17 & 42,2 \\
\hline & 3 & Kurang & 9 & 25 \\
\hline & \multicolumn{2}{|c|}{ Jumlah } & 36 & 100 \\
\hline
\end{tabular}

menggunakan metode diskriptif yaitu suatu metode penelitian yang dilakukan dengan tujuan untuk mengetahui tingkat pengetahuan keluarga tentang perawatan pasien fraktur di rumah.

Tempat penelitian diRSUD Arifin Achmad Kota Pekanbaru

Populasi dalam penelitian adalah seluruh keluarga pasien yang mengalami fraktur yang sedang di rawat di ruang Dahlia RSUD arifin achmad.

Pengambilan sampel dalam penelitian ini menggunakan tehnik total sampling yaitu total seluruh sampel yang di rawat di ruang cendrawasi II RSUD Arifin Achmad Kota Pekanbaru yang akan pulang.

\begin{tabular}{|l|l|l|l|}
\hline No & Kategori & $\begin{array}{l}\text { Frekuensi } \\
(\mathbf{f})\end{array}$ & $\begin{array}{l}\text { Persentase } \\
(\boldsymbol{\%})\end{array}$ \\
\hline 1 & Baik & 14 & 38,9 \\
\hline 2 & Cukup & 14 & 38,9 \\
\hline 3 & Kurang & 8 & 22,2 \\
\hline \multicolumn{2}{|l}{ Jumlah } & $\mathbf{3 6}$ & $\mathbf{1 0 0}$ \\
\hline
\end{tabular}

HASIL DAN PEMBAHASAN

Penelitian ini di lakukan Responden 36 orang. Data yang di peroleh di 
kelompokkan sesuai dengan kriteria objek yang diteliti dan selanjutnya disajikan dalam bentuk tabel distribusi frekuensi.

\section{Tabel 1}

Distribusi Frekuensi Responden Berdasarkan Umur di Ruang Dahlia RSUD Arifin Achmad

\begin{tabular}{|l|l|l|l|}
\hline No & Kategori & $\begin{array}{l}\text { Frekuensi } \\
\text { (f) }\end{array}$ & $\begin{array}{l}\text { Persentase } \\
(\mathbf{\%})\end{array}$ \\
\hline 1 & $\begin{array}{l}20-\quad 29 \\
\text { Tahun }\end{array}$ & 14 & 38,8 \\
\hline 2 & $\begin{array}{l}30-39 \\
\text { Tahun }\end{array}$ & 10 & 27,7 \\
\hline 3 & $\begin{array}{l}40->64 \\
\text { tahun }\end{array}$ & 12 & 33,3 \\
\hline Jumlah & $\mathbf{3 6}$ & $\mathbf{1 0 0}$ \\
\hline
\end{tabular}

Dari Tabel 5.1 dapat dilihat bahwa usia yang menjadi responden mayoritas berumur 20-29 tahun sebanyak 14 orang $(38,8 \%)$ dan minoritas berumur 30-39 tahun sebanyak 10 orang $(27,7 \%)$.

Tabel 2

Distribusi Frekuensi Pengetahuan Responden tentang Pengertian Fraktur diDahlia RSUD Arifin Achmad Pekanbaru

\begin{tabular}{|l|l|l|l|}
\hline No & Kategori & $\begin{array}{l}\text { Frekuensi } \\
(\mathbf{f})\end{array}$ & $\begin{array}{l}\text { Persentas } \\
\text { e } \\
(\%)\end{array}$ \\
\hline 1 & Baik & 8 & 22,2 \\
\hline 2 & Cukup & 21 & 58,3 \\
\hline 3 & Kurang & 7 & 19,4 \\
\hline \multicolumn{2}{|l}{ Jumlah } & $\mathbf{3 6}$ & $\mathbf{1 0 0}$ \\
\hline
\end{tabular}

Dari tabel 2 dapat di lihat bahwa pengetahuan responden tentang pengertian fraktur di ruang Dahlia RSUD Arifin Achmad tahun cukup yaitu sebanyak 17 orang $(42,2 \%)$

Tabel 3
Distribusi Frekuensi Pengetahuan Responden tentang Cara Imobilisasi Pasien Fraktur di Ruang Dahlia RSUD Arifin Achmad Pekanbaru

Dari Tabel 3 dapat di lihat bahwah pengetahuan responden tentang cara imobilisasi di ruang Dahlia RSUD Arifin Achmad Pekanbaru, mayoritas baik sebanyak 14 orang $(38,9 \%)$ dan cukup sebanyak 14 orang $(38,9 \%)$.

Tabel 4

Distribusi Frekuensi Pengetahuan Responden Tentang Asupan Gizi pada Pasien Fraktur di Ruang Dahlia RSUD Arifin Achmad Pekanbaru

\begin{tabular}{|l|l|l|l|}
\hline No & Kategori & $\begin{array}{l}\text { Frekuensi } \\
\text { (f) }\end{array}$ & $\begin{array}{l}\text { Persentase } \\
(\%)\end{array}$ \\
\hline 1 & Baik & 14 & 38,9 \\
2 & Cukup & 0 & 0 \\
3 & Kurang & 22 & 61,1 \\
\hline Jumlah & $\mathbf{3 6}$ & $\mathbf{1 0 0}$ \\
\hline
\end{tabular}

Dari Tabel 4 dapat di lihat bahwa pengetahuan responden tentang asupan gizi pada pasien fraktur di ruang Dahlia RSUD Arifin Achmad Pekanbaru mayoritas kurang sebanyak 22 orang $(61,1 \%)$.

\section{Tabel 5}

Distribusi Frekuensi Pengetahuan Responden tentang Cara Pencegahan Infeksi pada Pasien fraktur di Ruang Dahlia RSUD Arifin Achmad Pekanbaru

Dari Tabel 5 dapat di lihat bahwa pengetahuan responden tentang cara pencegahan infeksi pada pasien fraktur di ruang Dahlia RSUD Arifin Achmad Pekanbaru mayoritas cukup sebanyak 21 orang $(58,3 \%)$.

\section{Tabel 6}

Distribusi Frekuensi Pengetahuan Responden tentang cara Perwatan Pasien Fraktur di Rumah di RSUD Arifin Achmad Pekanbaru 


\begin{tabular}{|l|l|l|l|}
\hline No & Kategori & $\begin{array}{l}\text { Frekuensi } \\
(\mathbf{f})\end{array}$ & $\begin{array}{l}\text { Persentase } \\
(\boldsymbol{\%})\end{array}$ \\
\hline 1 & Baik & 6 & 16,7 \\
\hline 2 & Cukup & 17 & 47,2 \\
\hline 3 & Kurang & 13 & 36,1 \\
\hline \multicolumn{2}{|l}{ Jumlah } & $\mathbf{3 6}$ & $\mathbf{1 0 0}$ \\
\hline
\end{tabular}

Dari tabel 6 dilihat bahwa pengetahuan responden tentang cara perwatan pasien fraktur di rumah di ruang Dahlia RSUD Arifin Achmad Pekanbaru 2013 mayoritas cukup sebanyak 17 orang $(36,1 \%)$.

Setelah di lakukan analisa data dan dilihat dari hasil yang diperoleh peneliti akan membahas beberapa hal sesuai dengan teori dari kepustakaan yang ada yang ditinjau dari data umum dan khusus.

Dari hasil penelitian pada tabel 1 diperoleh bahwa jumlah responden menurut umur lebih banyak berusia 20-29 tahun yaitu sebanyak 14 responden $(38,8 \%)$, yang berusia 30-39 tahun sebanyak 10 orang $(27,7 \%)$, yang berusia 40-64 tahun sebanyak 12 orang $(33,3 \%)$.

Dari hasil penelitian di ruang Dahlia RSUD Arifin Achmad Pekanbaru didapatkan banyak keluarga pasien yang berusia 20-29 tahun, pengetahuan responden tentang cara perawatan pasien fraktur di rumah dapat disimpulkan bahwa sebagian responden masih banyak yang belum mengetahui tentang bagaimana cara perawatan pasien fraktur di rumah.

Menurut asumsi peneliti, kurangnya pengetahuan responden dipengaruhi oleh usia. Menurut Notoatmodjo (2010), usia dapat mempengaruhi tingkat pengetahuan seseorang semakin tua usia seseorang semakin baik pula pengetahuannya, begitu pula sebaliknya semakin muda usia seseorang maka semakin sedikit pengalaman yang dimilikinya dan tentu semakin rendah pengetahuannya.

Pengetahuan Keluarga tentang Pengertian Fraktur. Dari hasil penelitian pada tabel 2 diperoleh bahwa pengetahuan responden tentang pengertian fraktur di rumah mayoritas responden berpengatahuan cukup yaitu sebanyak 17 orang (42\%), yang berpengetahuan baik yaitu sebanyak 10 orang $(27,8 \%)$ dan yang berpengetahuan kurang sebanyak 9 orang $(25 \%)$.

Cukupnya pengetahuan keluarga pasien fraktur yang dirawat di ruang Dahlia RSUD Arifin Achmad Pekanbaru tentang pengertian fraktur, ini disebabkan keluarga kurang mendapatkan informasi tentang perawatan pasien fraktur di rumah. Sehingga responden kurang mengetahui bagaimana cara perawatan pasien fraktur di rumah terutama mengenai pengertian fraktur.

Menurut Notoatmodjo (2010), usia dapat mempengaruhi tingkat pengetahuan seseorang semakin tua usia seseorang semakin baik pula pengetahuannya, begitu pula sebaliknya semakin muda usia seseorang maka semakin sedikit pengalaman yang dimilikinya dan tentu semakin rendah pengetahuannya.

Hal ini harus lebih ditanggapi oleh responden untuk segera mencari tahu tentang bagaimana perawatan pasien fraktur di rumah terutama mengenai pengertian fraktur itu sendiri.

a. Pengetahuan Keluarga Pengertian Keluarga tentang Cara Imobilisasi Pasien Fraktur di Rumah

Dari hasil penelitian pada tabel 3 diperoleh bahwa gambaran tingkat pengetahuan keluarga tentang imobilisasi pasien fraktur di rumah mayoritas baik sebanyak 14 orang $(38,9 \%)$, cukup sebanyak 14 orang $(38,9 \%)$, dan kurang sebanyak 8 orang $(22,2 \%)$. Sesuai dengan pendapat Notoatmodjo (2003), mengatakan bahwa semakin tinggi pendidikan seseorang semakin tinggi pula pengetahuan yang dimilikinya. Hal ini harus lebih ditanggapi oleh responden untuk segera mencari tau tentang cara perawatan pasien fraktur di rumah terutama mengenai cara imobilisasi pasien fraktur.

b. Pengetahuan Keluarga tentang Asupan Gizi pada Pasien Fraktur

Dari hasil penelitian pada tabel 4 di peroleh pengetahuan responden tentang 
asupan gizi pada pasien fraktur di rumah mayoritas responden kurang sebanyak 22 orang $(61,1 \%)$. Hal ini disebabkan keluarga kurang mendapatkan informasi dan mencerna informasi baik dari media masa seperti majalah, Koran, televisi dan melalui penyuluhan-penyuluhan.

Sesuai pendapat Roesli (2001), informasi atau penyuluhan kesehatan merupakan salah satu usaha membentuk individu keluarga dan masyarkat dalam meningkatkan kemampuan untuk meningkatkan kesehatan secara optimal. Hal ini menunjukkan bahwa kurangnya informasi atau penyuluhan kepada masyarakat tentang asupan gizi pada pasien fraktur. Semakin banyak informasi yang keluarga dapatkan mengenai asupan gizi pada pasien fraktur maka akan bisa dijadikan bekal dalam meningkatkan gizi pada pasien fraktur itu sendiri.

c. Pengetahuan Keluarga tentang Pencegahan Infeksi pada Pasien Fraktur

Dari hasil penelitian pada tabel 5 dapat dilihat bahwa pengetahuan responden tentang cara pencegahan infeksi pada pasien fraktur di rumah mayoritas responden berpengathuan cukup sebanyak 21 orang $(58,3 \%)$, baik sebanyak 8 orang $(22,2 \%)$ dan kurang sebanyak 7 orang $(19,4 \%)$. Hal ini disebabkan keluarga kurang mendapatkan informasi dan mencerna informasi baik dari media masa seperti majalah, Koran, televise dan melalui penyuluhan-penyuluhan.

Sesuai pendapat Roesli (2001), informasi atau penyuluhan kesehatan merupakan salah satu usaha membentuk individu keluarga dan masyarkat dalam meningkatkan kemampuan untuk meningkatkan kesehatan secara optimal. Hal ini menunjukkan bahwa kurangnya informasi atau penyuluhan kepada keluarga tentang pencegahan infeksi pada pasien fraktur. Semakin banyak informasi yang keluarga dapatkan mengenai pencegahan infeksi pada pasien fraktur maka akan bisa dijadikan bekal dalam pencegahan infeksi pada pasien fraktur itu sendiri.

d. Pengetahuan Responden tentang Cara Perawatan Pasien Fraktur di Rumah

Dari hasil penelitian pada tabel 6 dilihat bahwa pengetahuan responden tentang cara perwatan pasien fraktur di rumah di ruang Dahlia RSUD Arifin Achmad Pekanbaru, mayoritas cukup sebanyak 17 orang $(36,1 \%)$. Cukupnya pengetahuan responden tentang cara perawatan pasien fraktur di rumah disebabkan mayoritas pengetahuan rersponden tentang pengertian fraktur berpengetahuan cukup yaitu sebanyak 17 orang (42,2\%), mayoritas pengetahuan rersponden tentang imobilisasi fraktur adalah baik sebanyak 14 orang $(38,9 \%)$, mayoritas pengetahuan rersponden tentang asupan gizi pada pasien fraktur adalah kurang yaitu sebanyak 22 orang $(61,1 \%)$, mayoritas pengetahuan rersponden tentang pencegahan infeksi adalah cukup yaitu sebanyak 21 orang $(58,3 \%)$. Selain itu keluarga belum sepenuhnya memahami tentang bagaimana perawatan pasien fraktur di rumah, hal ini dibuktikan banyaknya pasien fraktur yang kontra ulang disebabkan oleh infeksi di area fraktur.

Sesuai pendapat Roesli (2001), informasi atau penyuluhan kesehatan merupakan salah satu usaha membentuk individu keluarga dan masyarkat dalam meningkatkan kemampuan untuk meningkatkan kesehatan secara optimal. Hal ini menunjukkan bahwa kurangnya informasi atau penyuluhan kepada keluarga tentang cara perawatan pasien fraktur di rumah. Semakin banyak informasi yang keluarga dapatkan mengenai cara perawatan pasien fraktur di rumah maka akan bisa dijadikan bekal dalam perawatan pasien fraktur di rumah.

Hal ini harus lebih ditanggapi oleh responden untuk segera mencari tahu tentang bagaimana cara perawatan pasien fraktur di rumah. 


\section{SIMPULAN}

Berdasarkan hasil penelitian yang telah dilakukan di Dahlia RSUD Arifin Achmad Pekanbaru tentang Gambaran Tingkat Pengetahuan Keluarga tentang Cara Perawatan Pasien Fraktur di Rumah di Ruang Dahlia RSUD Arifin Achmad Pekanbaru diperoleh kesimpulan sebagai berikut :

1. Distribusi frekuensi pengetahuan responden tentang pengertian fraktur di Ruang Dahlia RSUD Arifin Achmad Pekanbaru, mayoritas cukup yaitu sebanyak 17 orang $(42,2 \%)$.

2. Distribusi frekuensi pengetahuan responden tentang cara imobilisasi pasien fraktur di Ruang Cendrawasih II RSUD Arifin Achmad Pekanbaru 2013 mayoritas baik sebanyak 14 orang $(38,9 \%)$ dan cukup sebanyak 14 orang $(38,9 \%)$.

3. Distribusi frekuensi pengetahuan responden tentang asupan gizi pada pasien fraktur di Ruang Dahlia RSUD Arifin Achmad Pekanbaru, mayoritas kurang sebanyak 22 orang $(61,1 \%)$.

4. Distribusi frekuensi pengetahuan responden tentang cara pencegahan infeksi pada pasien fraktur di Ruang Dahlia RSUD Arifin Achmad Pekanbaru, mayoritas cukup sebanyak 21 orang $(58,3 \%)$

5. Distribusi frekuensi pengetahuan responden tentang cara perawatan pasien fraktur di rumah di ruang Dahlia RSUD Arifin Achmad Pekanbaru mayoritas berpengetahuan cukup sebanyak 17 orang $(36,1 \%)$.

\section{UCAPAN TERIMAKASIH}

Terimakasih kepada RSUD Arifin Achmad yang telah memberikan tempat penelitian dan pihak keluarga yang bersedia untuk dijadikan responden bagi penelitian ini.

\section{DAFTAR PUSTAKA}

Alimun, H, Aziz. 2005. Riset Keperawatan dan Penulisan Ilmiah. Jakarta: Salemba Medika 2011. Metode Penelitian Kebidanan dan Teknik Analisa Data. Jakarta: salemba Medika

Alderink. 1991. Review of Anonimy Mechanics and Function. Jakarta: Rineka Cipta

Arikunto, Suharsimi. 2006. Prosedur Penelitian Suatu PEndekatan Praktek. Jakarta: Rineka Cipta

Black. 1997. Medical Surgical Nursing.philadelpia: WB Saunders Company

Depdiknas. 2006. Sistem Pendidikan Nasional Indonesia. http://www.google.co.id

Doenges, M. E. 1999. Rencana Asuhan Keperawatan, Pedoman untuk Perencanaan dan Pendokumentasian Pasien. Ed. 3. Jakarta: EGC

Husada, Dian. 2009. Sosiologi Dasar. Jakarta: Gramedia Pustaka Utama

Lewis. 2000. Medical Surgical Nursing. St Louis: Mosby

Nursalam. 2003. Konsep dan Penerapan Metodologi Penelitian Ilmu Keperawatan. Jakarta: Salemba Medika

Notoatmodjo. 2005. Metodologi Penelitian Kesehatan. Jakarta: Rineka Cipta

Pratomo, Arif. 2008. Pengenalan Pengetahuan Dasar. Jakarta: Salemba Medika

Price, S. A. 1995. Patofisiologis: Konsep Klinis Proses-proses Penyakit. Jakarta: Rineka Cipta 
Siswono. 2006. Dalam

http://www.Mediaindo.co.id

Silvia. 2001. Anatomi FIsiologi. Jakarta: Bumi Aksara

Sunita, DR, Alamtsier. 205. Penuntun Diet Instalasi Gizi. Jakarta: Gramedia Pustaka Utama

Smeltzer, S.C. 2002. Medical Surgical Nursing Brunner \& Suddart. Jakarta: EGC

Kunto, Ari. 1998. Kedokteran Bedah Orthophedy. Jakarta: Gramedia 